\title{
High-Temperature Corrosion of HVAF-Sprayed Ni-Based Coatings for Boiler Applications
}

\author{
J. Eklund ${ }^{1}$ D $\cdot$ J. Phother $^{1} \cdot$ E. Sadeghi ${ }^{2} \cdot$ S. Joshi ${ }^{2} \cdot$ J. Liske $^{1}$
}

Received: 7 November 2018 / Revised: 23 February 2019 / Published online: 14 March 2019

(c) The Author(s) 2019

\begin{abstract}
The present study investigates the initial corrosion behaviour of HVAF-sprayed $\mathrm{NiCr}, \mathrm{NiAl}$ and NiCrAlY coatings in two different environments, $\mathrm{O}_{2}+\mathrm{H}_{2} \mathrm{O}$ and $\mathrm{O}_{2}+\mathrm{H}_{2} \mathrm{O}+\mathrm{KCl}$ at $600{ }^{\circ} \mathrm{C}$ for up to $168 \mathrm{~h}$ in order to evaluate the possibility of utilizing such coatings in biomass- and waste-fired boilers. SEM/EDX analysis showed that all coatings displayed a protective behaviour in $\mathrm{O}_{2}+\mathrm{H}_{2} \mathrm{O}$. Upon addition of $\mathrm{KCl}$ $\left(\mathrm{O}_{2}+\mathrm{H}_{2} \mathrm{O}+\mathrm{KCl}\right)$, the corrosion behaviour of the $\mathrm{NiCr}$ coating drastically changed as it formed a thick oxide layer and displayed major chlorine diffusion down to the substrate. The NiCrAlY coating displayed a significantly better corrosion resistance with only minor oxide formation. The $\mathrm{NiAl}$ coating exhibited a protective behaviour similar to when exposed in the absence of $\mathrm{KCl}$ indicating that a thin protective oxide has formed on the coating surface. The performance of the NiAl and NiCrAlY coatings is promising for future studies with long-term exposures in more corrosive environments such as in a biomass- and waste-fired boiler.
\end{abstract}

Keywords Ni-based coatings $\cdot \mathrm{HVAF} \cdot \mathrm{KCl}$-induced corrosion $\cdot$ Biomass $\cdot$ Waste

\section{Introduction}

In today's society, renewable and more $\mathrm{CO}_{2}$ neutral fuels (compared to fossil fuels) are becoming increasingly important. The use of fossil fuels is one of the main problems when it comes to the emission of $\mathrm{CO}_{2}$ [1] and the substitution of these with more $\mathrm{CO}_{2}$ neutral fuels is crucial to reduce the negative impacts on the environment. Biomass and certain types of waste are good candidates for substitution of fossil fuels since they are both renewable and have a lower net emission of $\mathrm{CO}_{2}$ compared to fossil fuels. However, a major issue with the combustion of these fuels

J. Eklund

johek1@chalmers.se

1 Energy and Materials, Department of Chemistry and Chemical Engineering, Chalmers University of Technology, 41296 Göteborg, Sweden

2 Department of Engineering Science, University West, 46153 Trollhättan, Sweden 
is the resulting corrosive environment, which leads to accelerated degradation of the boiler components [2-4]. The main reasons behind the severe corrosivity are the large amounts of alkali chlorides and $\mathrm{HCl}(\mathrm{g})$ in the flue gas released during combustion. This results in economic problems for the boiler operators since the maintenance costs are greatly increased. The corrosion attack is especially severe for the superheaters, due to the high material temperatures these exhibit. Since the electrical efficiency of the combustion process increases with the steam temperature of the boiler, a high steam temperature is desired. However, as the steam temperature of the boiler is increased, the severity of the corrosion attack on the superheaters is even further increased. Since the combustion environment in a fossil fuel-fired boiler is less corrosive than a biomass- and waste-fired boiler, the steam temperature can be set higher in the former case, leading to a higher electrical efficiency. To be able to compete with the electricity production from fossil fuels, more corrosion-resistant materials are needed for the heat exchangers (especially superheaters) in a biomassand waste-fired boiler. Furthermore, this improvement needs to be balanced against the overall economy of the plant, not leading to greatly increased costs.

In general, a more corrosion-resistant material, i.e. high-alloyed steel, costs more than a less corrosion-resistant material, i.e. low-alloyed steel. Apart from the economical aspect, the mechanical properties are often negatively affected by the addition of certain alloying elements $(\mathrm{Cr}, \mathrm{Si}, \mathrm{Al}$, etc.) [5-7]. The inclusion of these elements may therefore lead to decreased pressure bearing capabilities of the boiler components as well as a reduced fabricability. A possible solution for this problem is to use high-alloyed steel/Ni-based alloys in the form of a coating. In this way, a low-alloyed steel substrate, with good mechanical properties, contributes to the pressure bearing capabilities, while the high-alloyed Fe- or Ni-based coating contributes to increasing the corrosion resistance. Apart from combining increased corrosion resistance with good mechanical properties, using a coating is also usually more economically favourable. It also facilitates the introduction of new alloy compositions since it is not necessary to perform pressure bearing tests.

Previous use of coatings for corrosion resistance, using thermal spraying techniques such as arc spray, has encountered problems regarding porosity, oxide formation during spraying as well as poor adherence of coating to the substrate. These problems have resulted in failure of the coating to act as a corrosion protection $[8,9]$. A more novel thermal spraying technique, compared to the previously mentioned, is HVOF (high-velocity oxygen fuel) which is able to form denser coatings with lower oxide content. For corrosion protection, a low degree of porosity of the coating is crucial for a good performance. More recently, a new thermal spraying technique, HVAF (high-velocity air fuel), has been developed which can produce coatings with even lower degree of porosity (i.e. denser coating layer), minimal oxide formation during spraying and thus, reduced elemental depletion of the powder feedstock [10, 11]. This is due to the relatively low particle temperature and dwell time compared to $\operatorname{HVOF}[10,12,13]$.

The aim of this paper is to investigate the protectiveness (corrosion resistance as well as adherence and porosity) of three different HVAF-sprayed coatings with different coating chemistries ( $\mathrm{NiCr}, \mathrm{NiAl}$ and $\mathrm{NiCrAl}$ ) in a laboratory environment, relevant for the harsh environment of a biomass- and waste-fired boiler 
(high levels of water vapour and large amounts of $\mathrm{KCl}$ ). The aim is also to investigate the corrosion behaviour of a chromia former $(\mathrm{NiCr})$, an alumina former $(\mathrm{NiAl})$ and a combination of both $(\mathrm{NiCrAl})$.

\section{Experimental Procedures}

\section{Materials}

The substrate material used was the commercial low carbon steel-16Mo3 (in wt $\%$; $0.01 \mathrm{Cr}-0.3 \mathrm{Mo}-0.5 \mathrm{Mn}-0.3 \mathrm{Si}-0.15 \mathrm{C}-\mathrm{Bal}$. Fe). The alloy was obtained in the form of rods with a diameter of $25 \mathrm{~mm}$.

Three commercially available gas-atomized powders supplied by Höganäs $\mathrm{AB}$, i.e. NiCr, NiAl and NiCrAlY (see composition in Table 1), were used for the spraying onto the $16 \mathrm{Mo} 3$ substrate. Each of the powders had a particle size distribution of $45 \pm 22 \mu \mathrm{m}$.

\section{HVAF Spraying and Surface Preparation}

To produce the coatings, an HVAF gun (Uniquecoat M3 ${ }^{\mathrm{TM}}$, Oilville, VA, USA) was used. Prior to spraying, the $16 \mathrm{Mo} 3$ substrates were grit-blasted with alumina particles $(63 \pm 10 \mu \mathrm{m})$ for cleaning and roughening the surfaces to ensure good adherence of the coating. A $16 \mathrm{Mo} 3$ rod with a length of half a meter was fixed in a horizontal rotating mandrel for applying the coating on the cylindrical surface. The spraying parameters used to apply the coatings in this study are shown in Table 2 and are based on preliminary coating tests, conducted in order to achieve the least porous microstructure. After the coating had been applied, the rod was cut into cylinders of $5 \mathrm{~mm}$ length. The coatings were then applied on the flat faces of the cut pieces to ensure that the samples were coated on all sides, leaving no part of the substrate exposed. All coatings were sprayed to a thickness of roughly $300 \mu \mathrm{m}$. The coated samples were then ground and polished down to 4000 grits with $\mathrm{SiC}$ paper to achieve a smooth surface, resulting in coating thicknesses ranging from 215 to $260 \mu \mathrm{m}$.

Table 1 Nominal compositions of the three investigated coatings

\begin{tabular}{llllll}
\hline \multirow{2}{*}{ Powders } & \multicolumn{5}{l}{ Chemical composition $(w t \%)$} \\
\cline { 2 - 6 } & $\mathrm{Ni}$ & $\mathrm{Cr}$ & $\mathrm{Al}$ & $\mathrm{Y}$ & $\mathrm{O}$ \\
\hline $\mathrm{NiCr}$ & 78.6 & 21.3 & - & - & 0.1 \\
$\mathrm{NiAl}$ & 94.1 & - & 5.7 & - & 0.2 \\
$\mathrm{NiCrAlY}$ & 70.4 & 21.2 & 7.3 & 0.9 & 0.2 \\
\hline
\end{tabular}


Table 2 List of the spraying parameters used in this study

\begin{tabular}{ll}
\hline Spraying parameters & \\
\hline Nozzle type & $3 \mathrm{~L} 2 \mathrm{G}$ \\
Air pressure (Mpa) & 0.8 \\
Fuel 1 pressure-propane (MPa) & 0.7 \\
Fuel 2 pressure-propane (Mpa) & 0.7 \\
Carrier gas pressure- $\mathrm{N}_{2}$ (Mpa) & 0.4 \\
Feed rate $(\mathrm{g} / \mathrm{min})$ & 150 \\
Pass velocity $(\mathrm{m} / \mathrm{min})$ & 50 \\
Pass spacing $(\mathrm{mm} / \mathrm{rev}$.) & 5 \\
Spray distance $(\mathrm{mm})$ & 300 \\
Number of passes & 8 \\
\hline
\end{tabular}

\section{Exposure}

Prior to exposure, the samples were weighed using a Sartorius ${ }^{\mathrm{TM}}$ balance with five-decimal accuracy. $\mathrm{KCl}$ was deposited onto the sample surface by spraying a 20/80 water-ethanol solution in which $\mathrm{KCl}$ had been dissolved. A flow of warm air was directed towards the sample during the spraying of the $\mathrm{KCl}$-containing solution to accelerate the drying of the solution. The amount of $\mathrm{KCl}$ deposited on the sample was controlled by gravimetry to obtain an amount of $1.0 \mathrm{mg} / \mathrm{cm}^{2}$.

The samples were exposed in a horizontal silica tube furnace in two different environments at $600{ }^{\circ} \mathrm{C}$ for $168 \mathrm{~h}$. The gas flow was calibrated using a Bios Definer $220 \mathrm{M}$ to achieve a total flow rate of $3.1 \mathrm{~cm} / \mathrm{s}$ and a gas compositions consisting of $5 \% \mathrm{O}_{2}+20 \% \mathrm{H}_{2} \mathrm{O}+\mathrm{N}_{2}$ (Bal.). The samples were exposed both with and without $\mathrm{KCl}$ (reference exposure) deposited on the surface. Each sample was mounted vertically in an alumina boat parallel to the gas flow. Each exposure contained two samples exposed in parallel. After exposure, the samples were weighed and mass gains were recorded. Each type of coating was exposed multiple times in order to ensure reproducibility.

\section{Analysis}

Cross sections of the samples were prepared by attaching a thin silicon wafer onto the surface of the sample using a glue well suited for metals (Loctite 415). After the glue had dried for about $24 \mathrm{~h}$, the samples were dry cut with a low-speed diamond saw at the position of the silicon wafer. The cross section was milled using broad ion beam (BIB) with a Leica TIC $3 \mathrm{X}$ instrument to achieve more accurate analysis compared to a mechanically polished surface. The three argon guns of the BIB instrument were operated at $6.5 \mathrm{kV}$ for $10 \mathrm{~h}$. The cross sections of the exposed samples were analysed by means of scanning electron microscopy (SEM) using backscattered electrons (BSE) with an accelerating voltage of 10-20 kV using an FEI Quanta 200. Elemental analysis was performed using 
energy-dispersive X-ray (EDX) with the equipped Oxford Instruments X-Max ${ }^{\mathrm{N}}$ 80 T EDX detector.

\section{Results}

\section{Gravimetry}

$$
5 \% \mathrm{O}_{2}+20 \% \mathrm{H}_{2} \mathrm{O}+\mathrm{N}_{2}
$$

The samples exposed in the absence of $\mathrm{KCl}$ exhibited mass gains in the order of $0.1-0.2 \mathrm{mg} / \mathrm{cm}^{2}$, see Fig. 1. (Mass gains of $\mathrm{NiCr}$ and $\mathrm{NiCrAlY}$ coatings are the same as presented in [11].) A 304L bulk sample was exposed for reference and exhibited a lower mass gain compared to the coated samples and was close to $0 \mathrm{mg} / \mathrm{cm}^{2}$ (slightly negative value possibly due to $\mathrm{Cr}$ evaporation). The mass gain was slightly decreased when going from $\mathrm{NiCr}$ to NiAl and finally NiCrAlY. The relatively high mass gains of the coatings resulted in calculated oxide thicknesses in the range of $0.6-1.0 \mu \mathrm{m}$. This calculation was based on nickel oxide $(\mathrm{NiO})$ and on the assumption that the total weight gain originates from the density change due to the ingress of oxygen. However, the metallic lustre on the surface of the exposed samples still remained, indicating oxide thicknesses in the range of $50-200 \mathrm{~nm}$.

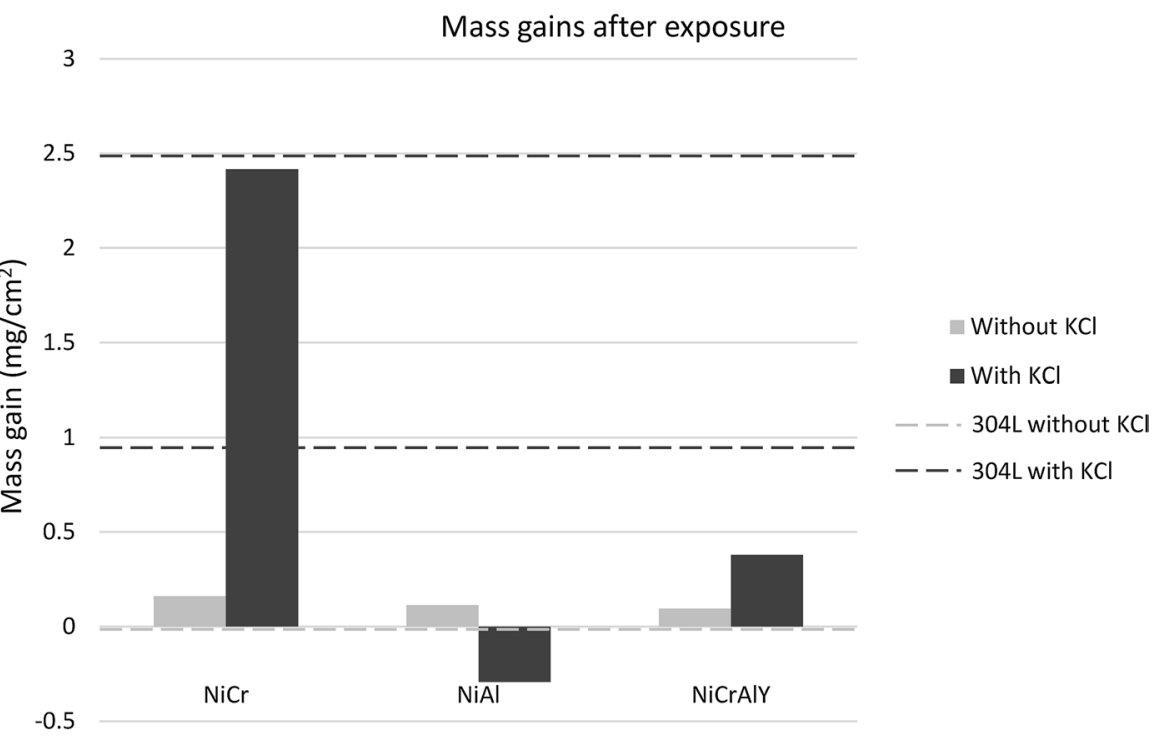

Fig. 1 Mass gains of coated samples after exposure for $168 \mathrm{~h}$ in $5 \% \mathrm{O}_{2}+20 \% \mathrm{H}_{2} \mathrm{O}+\mathrm{N}_{2}$ at $600{ }^{\circ} \mathrm{C}$ with and without $\mathrm{KCl}$ present. The mass gains of bulk 304L samples in the respective environments are displayed by dashed lines. The dashed lines for 304L in the presence of $\mathrm{KCl}$ show minimum and maximum mass gains, and they are based on the measured oxide thickness 
$5 \% \mathrm{O}_{2}+20 \% \mathrm{H}_{2} \mathrm{O}+\mathrm{N}_{2}+\mathrm{KCl}$

In the presence of $\mathrm{KCl}$, the mass gains of the coatings differed significantly, see Fig. 1. The NiCr-coated samples exhibited large average mass gains (of roughly $2.5 \mathrm{mg} / \mathrm{cm}^{2}$ ) which corresponds to a calculated oxide thickness of about $17 \mu \mathrm{m}$ based on $\mathrm{NiO}$. The NiCrAlY-coated samples showed a significantly lower average mass gain of about $0.4 \mathrm{mg} / \mathrm{cm}^{2}$ corresponding to a calculated thickness of about $3 \mu \mathrm{m}$ based on $\mathrm{NiO}$. The NiAl-coated samples exhibited mass loss, indicating that the weight gain from oxide formation was lower than the weight loss due to evaporation of $\mathrm{KCl}$. The $304 \mathrm{~L}$ bulk samples displayed mass gains in the range of $0.9-2.5 \mathrm{mg} / \mathrm{cm}^{2}$ which is in the same range as the NiCr-coated samples and higher than the NiAl- and NiCrAlY-coated samples.

\section{Microstructure}

$5 \% \mathrm{O}_{2}+20 \% \mathrm{H}_{2} \mathrm{O}+\mathrm{N}_{2}$

The cross sections of the coatings after exposure in the absence of $\mathrm{KCl}$ were investigated using SEM. As seen in Fig. 2, the NiCr coating has not formed a thick oxide

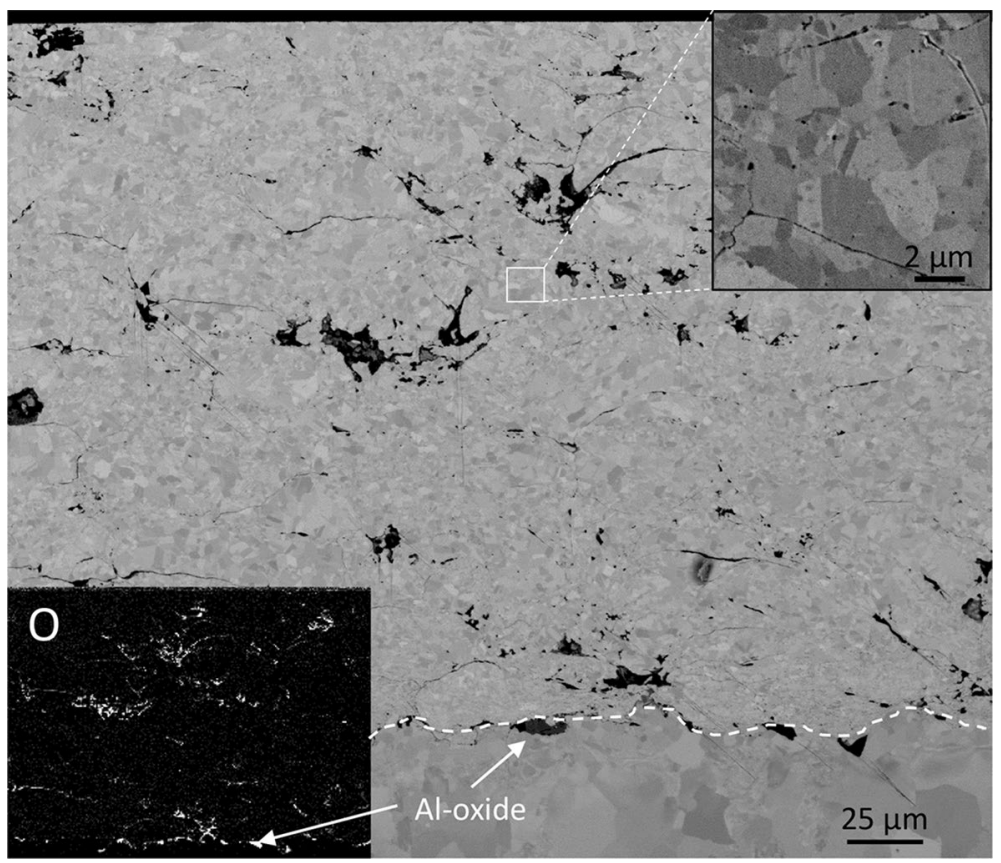

Fig. 2 SEM-BSE cross-sectional image of a $\mathrm{NiCr}$ coating after exposure in $5 \% \mathrm{O}_{2}+20 \% \mathrm{H}_{2} \mathrm{O}+\mathrm{N}_{2}$ at $600{ }^{\circ} \mathrm{C}$ for $168 \mathrm{~h}$. EDX map for oxygen added in bottom left corner showing oxide formation in pores. The dashed line shows the coating/substrate interface. Remaining Al oxide from grit blasting of substrate observed at coating/substrate interface 

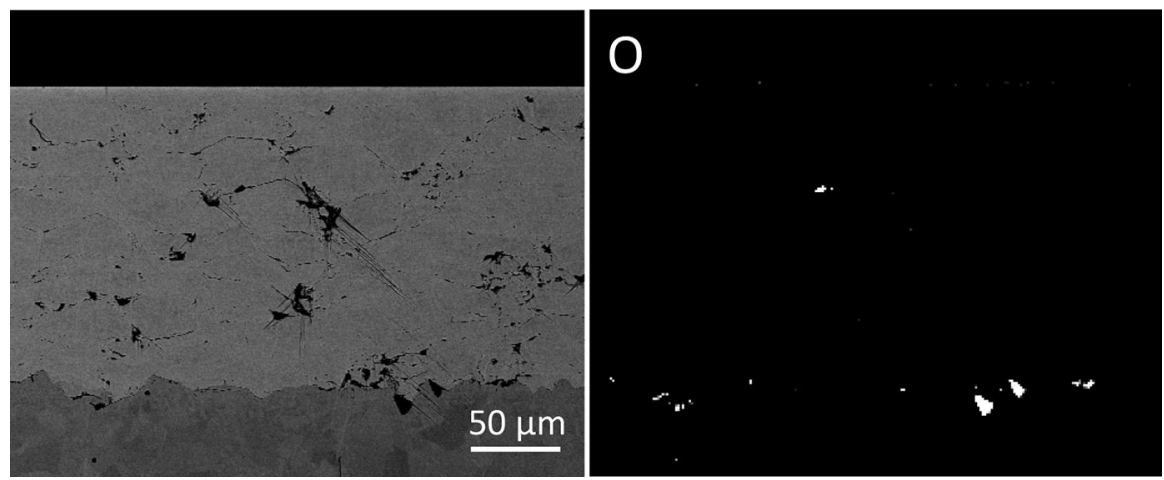

Fig. 3 SEM-BSE cross-sectional image of a non-exposed NiCr-coated sample (left) and EDX map for oxygen showing no oxide formation oxide formation in pores. Remaining Al oxide from grit blasting of substrate observed at coating/substrate interface

which indicates that it has retained a thin protective oxide on the surface of the coating. However, a significant degree of porosity can be observed in the coating and EDX analysis showed oxide formation in and along the pores. A non-exposed coated sample, analysed with SEM/EDX, showed no indications of oxide formation (apart from $\mathrm{Al}$ oxide remaining from grit blasting), see Fig. 3, but displays roughly the same degree of porosity as for the exposed coating. This indicates that the oxide

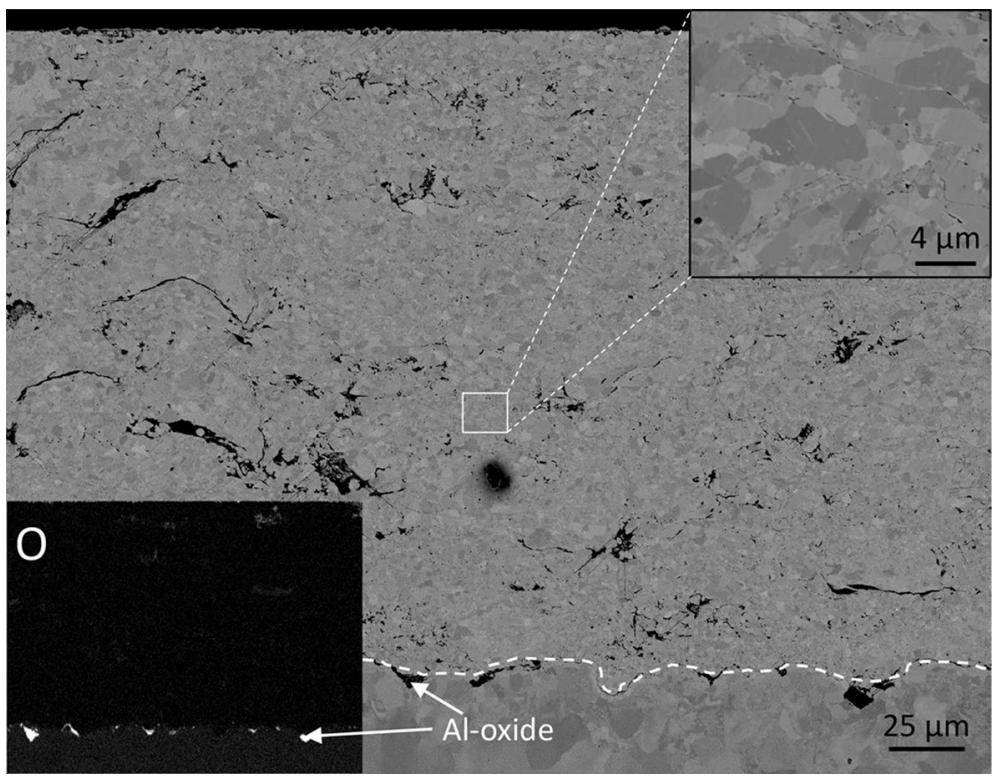

Fig. 4 SEM-BSE cross-sectional image of a NiAl coating after exposure in $5 \% \mathrm{O}_{2}+20 \% \mathrm{H}_{2} \mathrm{O}+\mathrm{N}_{2}$ at $600{ }^{\circ} \mathrm{C}$ for $168 \mathrm{~h}$. EDX map for oxygen added in bottom left corner showing no oxide formation in coating. The dashed line shows the coating/substrate interface. Remaining Al oxide from grit blasting of substrate observed at coating/substrate interface 
formation in the $\mathrm{NiCr}$ coating occurred during the exposure. The grain size of the $\mathrm{NiCr}$ coating ranged from 1 to $4 \mu \mathrm{m}$ and was quite evenly distributed. However, some areas contained larger grains, up to $10 \mu \mathrm{m}$ in diameter.

No thick oxide could be observed on the surface of the NiAl coating (see Fig. 4). The NiAl coating showed roughly the same amount of porosity as the $\mathrm{NiCr}$ coating. However, no oxide formation inside the coating was detected with EDX analysis, and only the $\mathrm{Al}$ oxide particles, remaining from the grit blasting of the substrate, resulted in oxygen signals in the EDX mapping. The grain size of the NiAl coating was evenly distributed and ranged from about 0.5 to $5 \mu \mathrm{m}$.

The NiCrAlY coating displayed a slightly higher degree of porosity (see Fig. 5), but the pores are smaller than in the $\mathrm{NiCr}$ and $\mathrm{NiAl}$ coatings. No thick oxide could be observed on the coating surface, and EDX analysis showed no oxide formation in the pores of the coating. The grain size for the NiCrAlY coating was smaller than the two other coatings and was varying from 0.2 to $1 \mu \mathrm{m}$.

Figure 6 shows high-magnification SEM images, focused at the coating/ substrate interface. An area with brighter contrast and smaller grains could be observed underneath the coating/substrate interface for all three coatings. The EDX point analyses detected $\mathrm{Ni}$ in this part of the substrate, implying that $\mathrm{Ni}$ has diffused from the coating to the substrate during the exposure. This has led to an austenitization of the upper part of the substrate. The amount of diffused

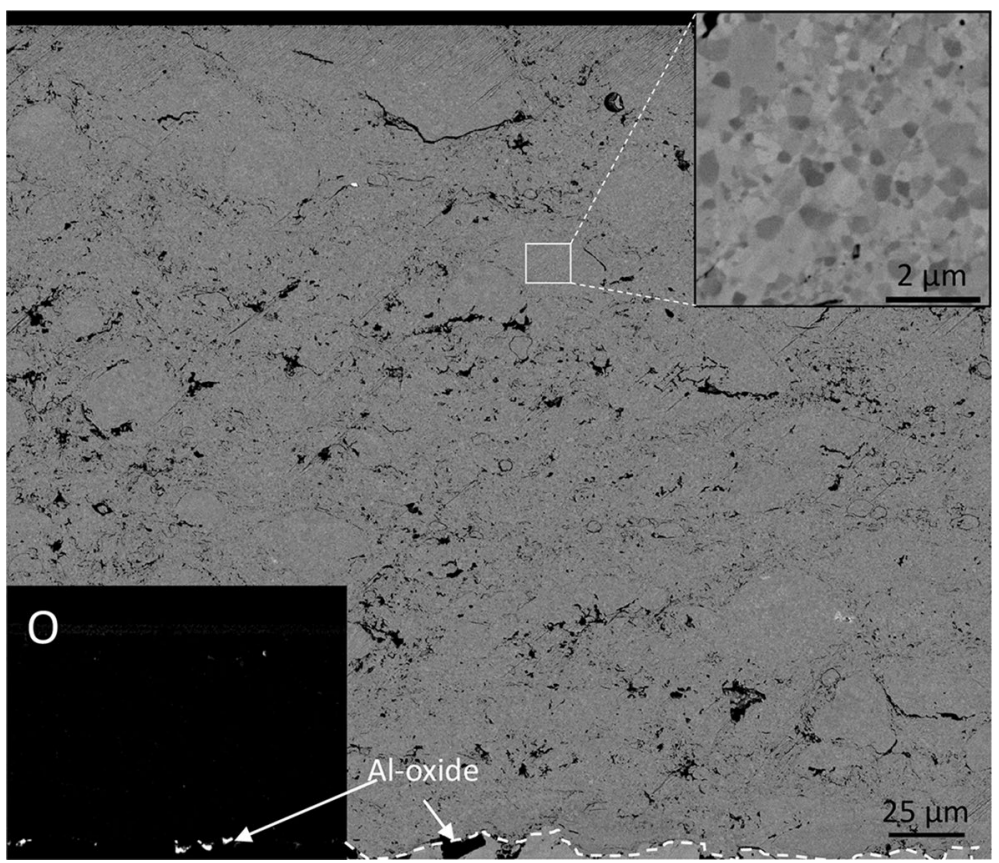

Fig. 5 SEM-BSE cross-sectional image of a NiCrAlY coating after exposure in $5 \% \mathrm{O}_{2}+20 \% \mathrm{H}_{2} \mathrm{O}+$ $\mathrm{N}_{2}$ at $600{ }^{\circ} \mathrm{C}$ for $168 \mathrm{~h}$. EDX map for oxygen added in bottom left corner showing no oxide formation in coating. The dashed line shows the coating/substrate interface. Remaining Al oxide from grit blasting of substrate observed at coating/substrate interface 

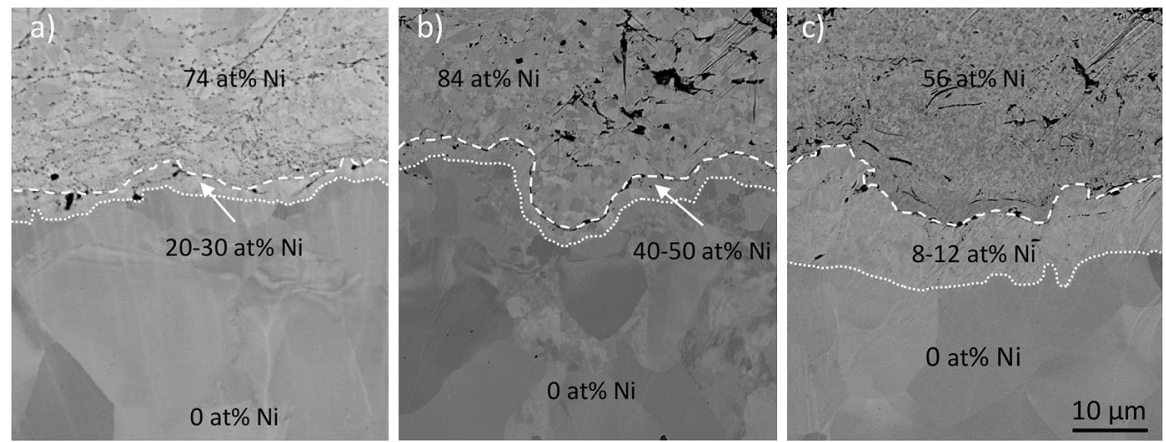

Fig. 6 SEM-BSE cross-sectional image of a NiCr coating, b NiAl coating and c NiCrAlY coating, focused on the coating/substrate interface, after exposure in $5 \% \mathrm{O}_{2}+20 \% \mathrm{H}_{2} \mathrm{O}+\mathrm{N}_{2}$ at $600{ }^{\circ} \mathrm{C}$ for $168 \mathrm{~h}$. The upper dashed line shows the coating/substrate interface. The lower dashed line shows the interface between austenitized (above)/ferritic(below) substrates

$\mathrm{Ni}$ and the depth to which it diffused differed between the coatings. For the $\mathrm{NiCr}$ and NiAl coatings, Ni diffusion to a depth of about $3 \mu \mathrm{m}$ into the substrate could be observed with Ni contents of 30-50 at\%. For the NiCrAlY coating, Ni diffusion to a depth of 10-20 $\mu \mathrm{m}$ into the substrate could be observed with Ni contents of 8-12 at\%. The depletion of $\mathrm{Ni}$ in the coating was minor (the Ni content decreased at most 5 at \%) with the depletion zone reaching no further than $1 \mu \mathrm{m}$ into the coating. Interdiffusion of $\mathrm{Cr}$ and $\mathrm{Al}$ from the coatings to the substrate was negligible.

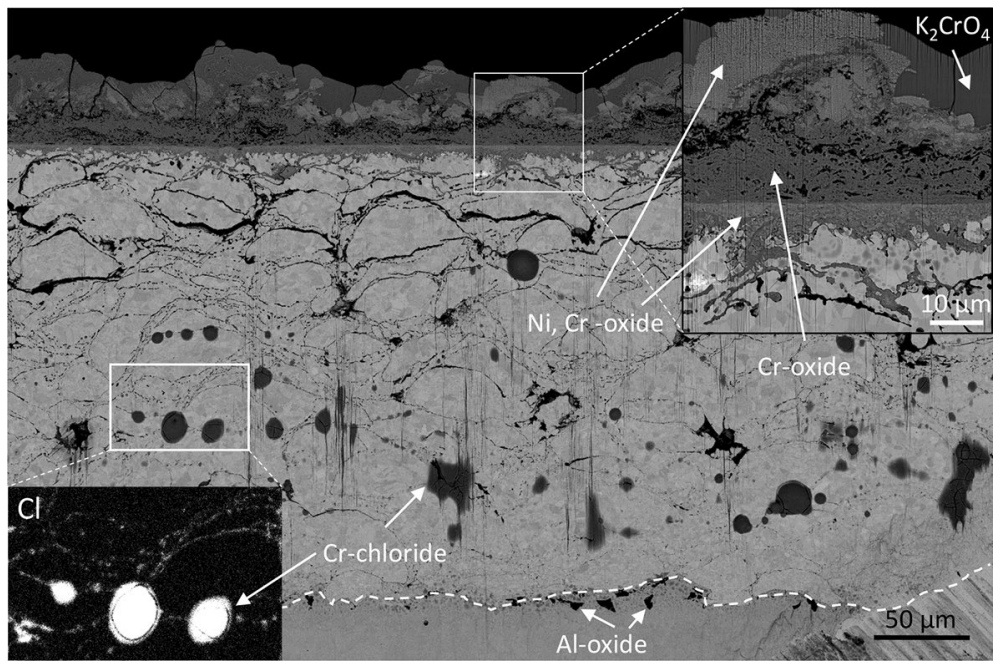

Fig. 7 SEM-BSE cross-sectional image of a $\mathrm{NiCr}$ coating after exposure in $5 \% \mathrm{O}_{2}+20 \% \mathrm{H}_{2} \mathrm{O}+\mathrm{N}_{2}$ at $600{ }^{\circ} \mathrm{C}$ with $\mathrm{KCl}$ present for $168 \mathrm{~h}$. The dashed line shows the coating/substrate interface. Remaining $\mathrm{Al}$ oxide from grit blasting of substrate observed at coating/substrate interface. The EDX map in the bottom left corner shows the presence of metal chlorides in the coating 


\section{$5 \% \mathrm{O}_{2}+20 \% \mathrm{H}_{2} \mathrm{O}+\mathrm{N}_{2}$ with $\mathrm{KCl}$}

The corrosion behaviour varied greatly between the different coatings when exposed in the presence of $\mathrm{KCl}$. The $\mathrm{NiCr}$ coating formed a 30-50 $\mu \mathrm{m}$ thick oxide on the surface, consisting of two layers (distinguished by the different contrasts), see Fig. 7. The EDX analysis indicates that the upper layer of the thick oxide consisted of a mixed Ni- and $\mathrm{Cr}$-containing oxide mixed with some $\mathrm{K}_{2} \mathrm{CrO}_{4}$. The underlying layer consisted mainly of a porous $\mathrm{Cr}$ oxide. Underneath, an inward-growing oxide had formed (about $15 \mu \mathrm{m}$ thick) which has grown along intersplat boundaries and consisted of both $\mathrm{Ni}$ and $\mathrm{Cr}$ oxides. Voids have begun to form in the coating as splats are separated, causing the intersplat boundaries to widen. This could be observed to a depth of about $75 \mu \mathrm{m}$. Further down in the coating the intersplat boundaries are distinguished by thin dark contrast lines. Chromium chlorides were detected deeper down in the coating as well as in the intersplat boundaries, see EDX map for $\mathrm{Cl}$ in Fig. 7. Metal chlorides (presumably chromium chlorides) were also detected at the coating/substrate interface, see Fig. 8.

The NiAl coating shows minimal corrosion attack (see Fig. 9) and has not formed a thick oxide on the coating surface, but an aluminium oxide has formed to a depth of $5 \mu \mathrm{m}$ into the coating. The sample displayed a slightly lower degree of porosity than the $\mathrm{NiAl}$ coating exposed without $\mathrm{KCl}$ present. No oxide formation could be observed in the pores of the coating, and no chloride could be detected inside the coating.

The NiCrAlY coating displayed roughly the same degree of porosity as the sample exposed without $\mathrm{KCl}$ present. It has formed a large amount of $\mathrm{K}_{2} \mathrm{CrO}_{4}$ on the surface where the $\mathrm{KCl}$ particles had been deposited prior to exposure, see Fig. 10.

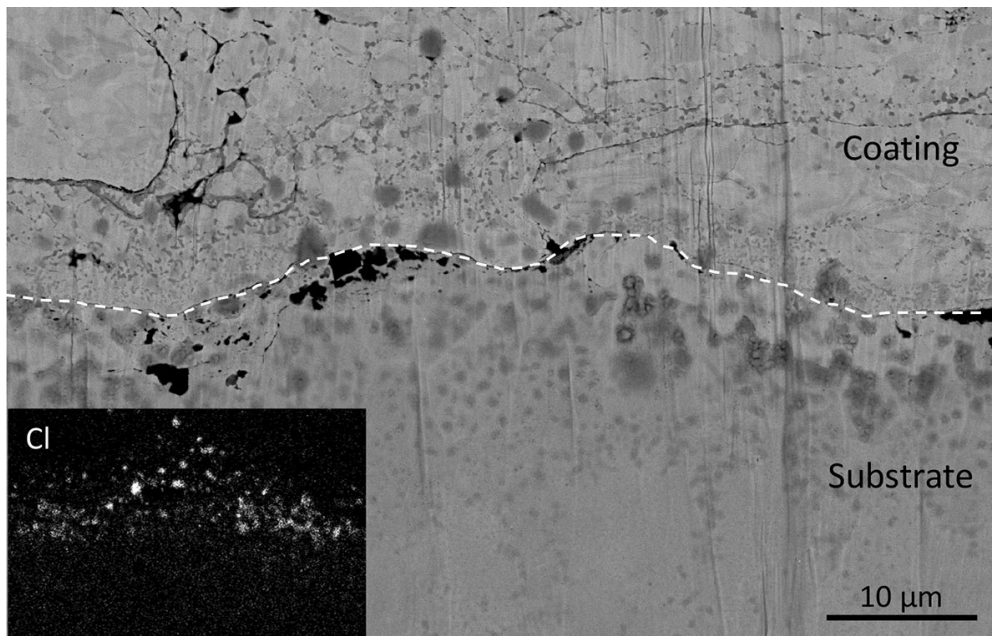

Fig. 8 SEM-BSE cross-sectional image of the coating/substrate interface of the NiCr coating after exposure in $5 \% \mathrm{O}_{2}+20 \% \mathrm{H}_{2} \mathrm{O}+\mathrm{N}_{2}$ at $600{ }^{\circ} \mathrm{C}$ with $\mathbf{~ K C l}$ present for $168 \mathrm{~h}$. The dashed line indicates the coating/substrate interface. The EDX map in the bottom left corner shows the presence of metal chlorides at the interface 


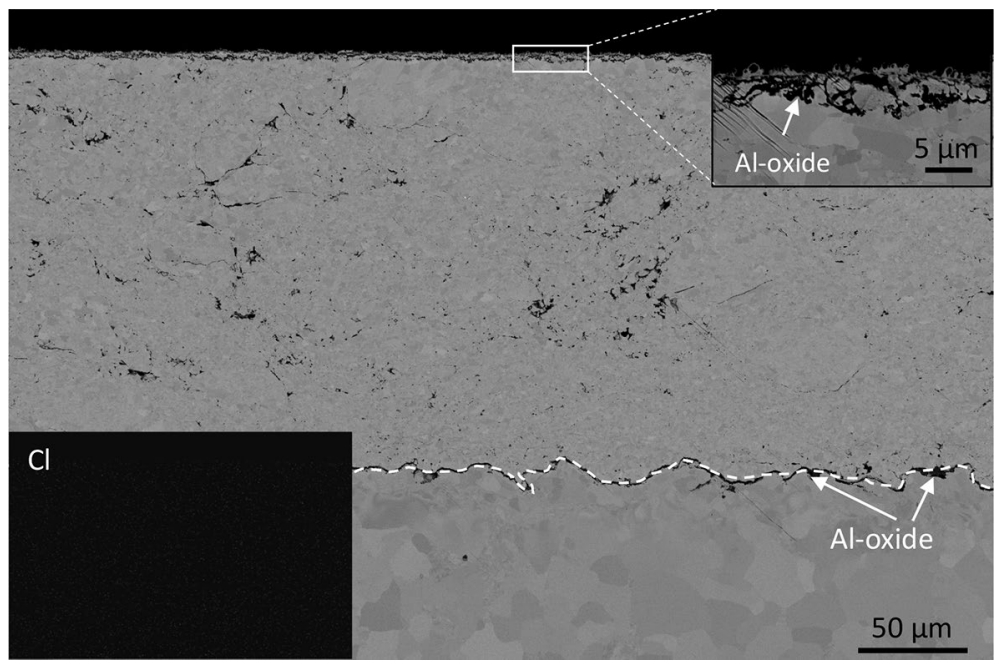

Fig. 9 SEM-BSE cross section image of a NiAl coating after exposure in $5 \% \mathrm{O}_{2}+20 \% \mathrm{H}_{2} \mathrm{O}+\mathrm{N}_{2}$ at $600{ }^{\circ} \mathrm{C}$ with $\mathrm{KCl}$ present for $168 \mathrm{~h}$. The dashed line indicates the coating/substrate interface. Remaining Al oxide from grit blasting of substrate observed at coating/substrate interface. The EDX map in the bottom left corner shows no presence of $\mathrm{Cl}$ in the coating

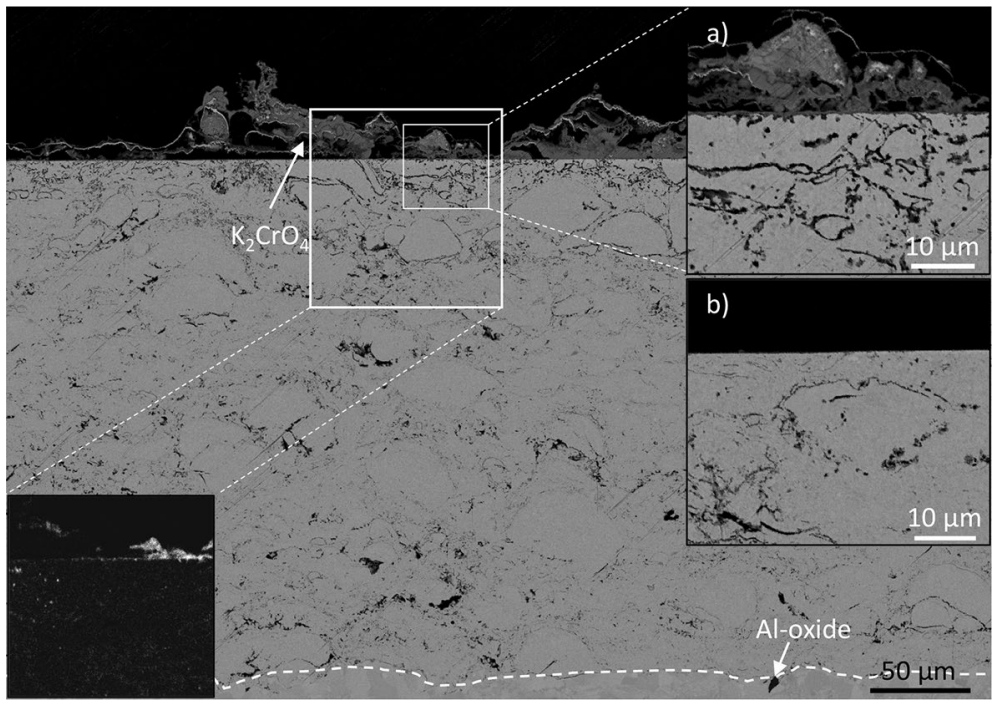

Fig. 10 SEM-BSE cross-sectional image of a NiCrAlY coating after exposure in $5 \% \mathrm{O}_{2}+20 \% \mathrm{H}_{2} \mathrm{O}$ $+\mathrm{N}_{2}$ at $600{ }^{\circ} \mathrm{C}$ with $\mathrm{KCl}$ present for $168 \mathrm{~h}$. The magnified images a and b show areas with and without $\mathrm{K}_{2} \mathrm{CrO}_{4}$ present, respectively. The EDX map in the bottom left corner displays no presence of $\mathrm{Cl}$ inside the coating. The dashed line indicates the coating/substrate interface. Remaining Al oxide from grit blasting of substrate observed at coating/substrate interface 
Apart from this, no thick oxide was observed on the coating surface. Underneath the $\mathrm{K}_{2} \mathrm{CrO}_{4}$ particles, dark contrast lines could be observed to a depth of about $20 \mu \mathrm{m}$. EDX analysis displayed enrichment of $\mathrm{Cr}, \mathrm{Al}$ and oxygen at these lines which indicates the formation of $\mathrm{Cr}$, and $\mathrm{Al}$ oxide. No further oxide formation is observed in the pores deeper in the coating. No chlorides could be detected within the coating, see EDX map for $\mathrm{Cl}$ in Fig. 10.

\section{Discussion}

The aim of this study was to investigate the performance of three different HVAFsprayed coatings regarding adherence and corrosion protection in a highly corrosive environment at high temperature. This was achieved by exposing the coatings in two different laboratory environments: one mildly corrosive environment $\left(\mathrm{O}_{2}+\mathrm{H}_{2} \mathrm{O}\right)$ and a harsher environment $\left(\mathrm{O}_{2}+\mathrm{H}_{2} \mathrm{O}+\mathrm{KCl}\right)$. Subsequently, gravimetrical and microstructural analysis was performed.

\section{General Observations: Coating Microstructure}

The coatings used in this study were produced by spraying, using a M3 ${ }^{\mathrm{TM}} \mathrm{HVAF}$ gun, onto a $16 \mathrm{Mo} 3$ steel substrate. Prior to spraying, the substrate was grit-blasted to achieve an improved adhesion of the coating. Remaining $\mathrm{Al}$ oxide from the grit blasting can therefore be observed at the coating/substrate interface.

The coatings displayed similar microstructure with some porosity, see Figs. 2, 4 and 5 . The degree of porosity differed slightly between the coatings. The NiCr coating exhibited larger pores, mostly distributed along the intersplat boundaries, see Fig. 2. This type of large porosity was not observed to the same extent for the NiAl and NiCrAlY coatings. Instead, these coatings exhibited smaller pores evenly distributed in the coating, see Figs. 4 and 5. Since the corrosive species are small, the lower diameter pores may still have a major negative effect on the corrosion protection of the coating as these may act as diffusion paths for corrosive species, enabling them to penetrate the coating. However, the severity of the porosity for the corrosion protection also depends on the degree of open pores. If the majority of the pores are closed, the diffusion of the corrosive species through the coating may not be as severe. The grain size of the $\mathrm{NiCr}$ and $\mathrm{NiAl}$ coatings differed significantly to that of the NiCrAlY coating. The former displayed grain sizes in the range of $0.5-5 \mu \mathrm{m}$, while the latter exhibited grain sizes in the range of $0.2-1 \mu \mathrm{m}$. Smaller grains could influence the diffusion of $\mathrm{Cr}$ and/or $\mathrm{Al}$ to the surface of the coating and facilitate the formation of $\mathrm{Cr}_{2} \mathrm{O}_{3}$ and $\mathrm{Al}_{2} \mathrm{O}_{3}$.

A commonly occurring problem regarding coatings in high-temperature applications is the interdiffusion of alloying elements from the coating to the substrate [14, 15]. This has been shown to cause a reduction of the amounts of corrosion resistanceenhancing elements (such as $\mathrm{Cr}$ and $\mathrm{Al}$ ) in the coating as well as reduced mechanical strength in the interdiffusion zone [16]. The latter can result in reduced pressure bearing capabilities and spallation of the protective coating. After exposure in $\mathrm{O}_{2}+\mathrm{H}_{2} \mathrm{O}$ 
at $600{ }^{\circ} \mathrm{C}$ for $168 \mathrm{~h}$, all coatings exhibited some degree of interdiffusion, see Fig. 6 (occurred with $\mathrm{KCl}$ present as well). Since the substrate, 16Mo3, is a ferritic steel and contains no $\mathrm{Ni}$, the driving force for diffusion from the coating to the substrate is high. The EDX analysis showed that the interdiffusion zone of the NiAl coating contained the highest amount of $\mathrm{Ni}(40-50$ at\%), followed by the $\mathrm{NiCr}$ coating in which the interdiffusion zone contained 20-30 at\% Ni. The interdiffusion zone of the NiCrAlY coating exhibited the lowest amount of $\mathrm{Ni}(8-12$ at\%) but reached deeper into the substrate compared to the other coatings. Due to the relatively high Ni contents in the interdiffusion zone, austenitization takes place, i.e. the ferritic phase is transformed into an austenitic phase. This has earlier been shown to occur in high-Cr ferritic steels coated with metallic nickel [17]. Apart from the austenitization, the high-Cr steels formed brittle $\sigma$-FeCr phases which could lead to crack formation. Since the substrate used in this study, $16 \mathrm{Mo} 3$, contains very small amounts of $\mathrm{Cr}$, the formation of $\sigma$ - $\mathrm{FeCr}$ phases is not possible. However, austenitization can cause other mechanical problems because the austenitic phase has a substantially higher coefficient of thermal expansion compared to the ferritic phase $[18,19]$ which may result in mechanical stresses during cycling and in turn, the spallation of the protective coating. The amount of $\mathrm{Ni}$ in the interdiffusion zone increased with the amount of $\mathrm{Ni}$ in the coating. This may be explained by an increased driving force for diffusion due to an increased element activity gradient of $\mathrm{Ni}$ between the coating and the substrate. Hence, even though the interdiffusion zone is deeper for the NiCrAlY coating, the total amount of Ni diffused into the substrate is lower compared to the other two coatings. It is expected that also the diffusion properties of the coating (and substrate) will influence the depth and composition of the interdiffusion zone. Interdiffusion of $\mathrm{Cr}$ and $\mathrm{Al}$ was found to be negligible. The low interdiffusion of $\mathrm{Al}$ to the low-alloyed steel substrate agrees well with previous studies which show that $\mathrm{Al}$ interdiffusion is insignificant at $600{ }^{\circ} \mathrm{C}$ [20]. No negative effects of the interdiffusion on the performance of the coatings were observed in this study. However, it is important to point out that the current study focused on the initial stages of corrosion and/or coating failure. Hence, in order to investigate these coatings for a future full-scale application, thermal cycling and/or longer exposure times need to be investigated.

\section{Oxidation in Water Vapour: Absence of $\mathrm{KCl}$}

It has previously been showed that the HVAF-sprayed $\mathrm{NiCr}, \mathrm{NiAl}$ and $\mathrm{NiCrAlY}$ coatings succeed in protecting the $16 \mathrm{Mo} 3$ substrate in ambient air at $600{ }^{\circ} \mathrm{C}$ as they form thin protective oxides on the surface [21]. Due to the high levels of water vapour in the flue gas in a biomass- and waste-fired boiler, the influence of water vapour of the corrosion protective performance of the coatings is of great importance.

It has been shown that chromia-forming steels accelerate corrosion rates in water vapour-containing environments at high temperatures due to the formation of chromium(VI) oxide hydroxide $\left(\mathrm{CrO}_{2}(\mathrm{OH})_{2}\right)$ [22], see Reaction 1.

$$
\left.\frac{1}{2} \mathrm{Cr}_{2} \mathrm{O}_{3}(\mathrm{~s})+\frac{3}{4} \mathrm{O}_{2}(\mathrm{~g})+\mathrm{H}_{2} \mathrm{O}(\mathrm{g}) \rightleftharpoons \mathrm{CrO}_{2}(\mathrm{OH})_{2}(\mathrm{~g}), \Delta \mathrm{G}=81.1 \frac{\mathrm{kJ}}{\mathrm{mol}} \quad \text { (Reaction } 1\right)
$$


$p\left(\mathrm{CrO}_{2}(\mathrm{OH})_{2}\right)=2.97 \times 10^{-7}$ atm (calculated with the following parameters and $K_{\text {eq }}$ from Factsage; $T=600{ }^{\circ} \mathrm{C}, \mathrm{pO}_{2}=0.05, \mathrm{pH}_{2} \mathrm{O}=0.2$ )

The performance of HVAF-sprayed $\mathrm{NiCr}$ and NiCrAlY coatings in water vapourcontaining environment was therefore recently investigated by exposing them in 5\% $\mathrm{O}_{2}+20 \% \mathrm{H}_{2} \mathrm{O}+\mathrm{N}_{2}$ (bal.) at $600{ }^{\circ} \mathrm{C}$ for $168 \mathrm{~h}$ [11]. It was shown that both coatings formed thin protective oxides in the nanometre range.

Accordingly, the three coatings investigated in this study formed thin protective oxides on the surface, see Figs. 2, 4 and 5. However, this does not correlate with the mass gains which correspond to oxide thicknesses in the range of 0.6-1 $\mu \mathrm{m}$. This indicates oxide formation at flaws or inside the coating. The oxygen EDX map in Fig. 2 confirms the latter for the $\mathrm{NiCr}$ coating as oxygen is detected at a depth close to the coating-substrate interface. Since no oxide formation was detected for the non-exposed $\mathrm{NiCr}$ coating (Fig. 3), it can be concluded that the oxides in the exposed $\mathrm{NiCr}$ sample did not form during the spraying of the coating. The NiAl and NiCrAlY coatings did not display any oxide formation within the coating which indicates that the higher mass gain may be due to flaws in the coating, causing local corrosion attacks of the substrate. However, this could not be observed by either visual inspection or SEM analysis and can therefore not be confirmed.

\section{Oxidation in Water Vapour in the Presence of KCl}

It is well known that chromia-forming steels exhibit severe corrosion attacks in the presence of $\mathrm{KCl}$ at high temperatures due to the loss of the protective chromia as it reacts with the $\mathrm{KCl}$ to form $\mathrm{K}_{2} \mathrm{CrO}_{4}$ and $\mathrm{Cl}_{2}$, see Reaction 2 [23].

$$
\mathrm{Cr}_{2} \mathrm{O}_{3}(\mathrm{~s})+4 \mathrm{KCl}(\mathrm{s})+\frac{5}{2} \mathrm{O}_{2}(\mathrm{~g}) \rightleftharpoons 2 \mathrm{~K}_{2} \mathrm{CrO}_{4}(\mathrm{~s})+2 \mathrm{Cl}_{2}(\mathrm{~g}), \quad \Delta G=145.6 \frac{\mathrm{kJ}}{\mathrm{mol}}
$$

(Reaction 2)

$p\left(\mathrm{Cl}_{2}\right)=1.04 \times 10^{-6} \mathrm{~atm}$ (calculated with the following parameters and $K_{\text {eq }}$ from Factsage; $T=600^{\circ} \mathrm{C}, \mathrm{pO}_{2}=0.05, \mathrm{pH}_{2} \mathrm{O}=0.2$ )

However, in most cases, the presence of water vapour is high enough for Reaction 3 to occur, forming $\mathrm{HCl}(\mathrm{g})$ instead of $\mathrm{Cl}_{2}(\mathrm{~g})$ [23].

$$
\frac{1}{2} \mathrm{Cr}_{2} \mathrm{O}_{3}(\mathrm{~s})+2 \mathrm{KCl}(\mathrm{s})+\mathrm{H}_{2} \mathrm{O}(\mathrm{g})+\frac{3}{4} \mathrm{O}_{2}(\mathrm{~g}) \rightleftharpoons \mathrm{K}_{2} \mathrm{CrO}_{4}(\mathrm{~s})+2 \mathrm{HCl}(\mathrm{g}), \quad \Delta G=72.5 \frac{\mathrm{kJ}}{\mathrm{mol}}
$$

(Reaction 3)

$\mathrm{p}(\mathrm{HCl})=9.87 \times 10^{-4} \mathrm{~atm}$ (calculated with the following parameters and $K_{\text {eq }}$ from Factsage; $T=600^{\circ} \mathrm{C}, \mathrm{pO}_{2}=0.05, \mathrm{pH}_{2} \mathrm{O}=0.2$ )

The corrosion behaviour of HVAF-sprayed $\mathrm{NiCr}$, NiAl and NiCrAlY coatings has recently been investigated when exposed to ambient air at $600{ }^{\circ} \mathrm{C}$ with $\mathrm{KCl}$ present for $168 \mathrm{~h}$ [24]. It was shown that all three coatings managed to protect the substrate from corrosion attack during the time interval of the exposure. However, the corrosion protection differed significantly between the coatings. The NiCr coating formed an outward-growing oxide (up to $20 \mu \mathrm{m}$ thick) as well as an inward-growing oxide to a depth of roughly $30 \mu \mathrm{m}$. The NiCrAlY coating displayed less corrosion attack with only minor oxide formation dispersed in the upper part of the coating (to a depth of 
about $30 \mu \mathrm{m}$ ). The NiAl coating showed excellent performance regarding corrosion protection with no oxygen penetration and oxide formation inside the coating.

Since the combustion of biomass and waste results in a flue gas with high amounts of both water vapour and alkali compounds (such as alkali chlorides) [25, 26], the understanding of the corrosion behaviour of the coatings in an environment containing both of these corrosive species is of utmost importance. Thus, in this study, the coatings were exposed in water vapour and $\mathrm{KCl}$ simultaneously.

Introducing $\mathrm{KCl}$ to the water vapour-containing environment resulted in a drastic change in corrosivity, for the $\mathrm{NiCr}$ coating, see Fig. 7. This was displayed by the formation of metal chlorides throughout the coating and into the substrate as well as the formation of a thick corrosion product layer on the top surface. In contrast, both the $\mathrm{NiAl}$ and $\mathrm{NiCrAlY}$ coatings remained fairly protective in the presence of $\mathrm{KCl}$, see Figs. 1, 9 and 10. The NiCr coating exhibited similar degree of corrosion attack as the $304 \mathrm{~L}$ bulk sample, see Fig. 1. A thick outward-growing Ni- and Cr-rich oxide formed on the surface of the $\mathrm{NiCr}$ coating, mixed with large amounts of $\mathrm{K}_{2} \mathrm{CrO}_{4}$ as well as an inward-growing oxide. As the inward-growing oxide is growing along the intersplat boundaries, these seem to be expanding, resulting in a less dense coating. This may result in further corrosion due to the facilitation of the diffusion of corrosive species which eventually may leave the substrate vulnerable. The formation of $\mathrm{Cr}$ chlorides in the coating indicates that $\mathrm{Cl}$ is diffusing through the coating. According to the EDX map in Fig. 7, $\mathrm{Cl}$ is diffusing along the intersplat boundaries. Thus, even though the coating remains dense, $\mathrm{Cl}$ can diffuse all the way down to the substrate. This is confirmed in Fig. 8, as $\mathrm{Cl}$ is detected at the coating/substrate interface as well as in the substrate.

The $\mathrm{NiAl}$ coating, exposed in water vapour with $\mathrm{KCl}$ present, exhibited similar behaviour as when exposed in the absence of $\mathrm{KCl}$, see Fig. 9. No thick oxide was observed on the coating surface, but the formation of $\mathrm{Al}$ oxide can be seen reaching around $5 \mu \mathrm{m}$ into the coating. Underneath the Al oxide, neither oxide formation nor chloride penetration could be detected. This indicates that the $\mathrm{Al}$ oxide, formed in the upper part of the coating, prevents chloride from diffusing along the intersplat boundaries and therefore inhibits further corrosion and succeeds in protecting the substrate. Compared to the $\mathrm{Cr}$-rich oxide on the $\mathrm{NiCr}$ coating, the $\mathrm{Al}$ oxide does not break down. This may be because $\mathrm{KCl}$ does not react with $\alpha-\mathrm{Al}_{2} \mathrm{O}_{3}$. However, at the exposure temperature in this study, $\alpha-\mathrm{Al}_{2} \mathrm{O}_{3}$ may not form but instead the transient form of alumina, $\gamma-\mathrm{Al}_{2} \mathrm{O}_{3} \cdot \gamma-\mathrm{Al}_{2} \mathrm{O}_{3}$ has been shown to display less corrosion resistance in the presence of $\mathrm{KCl}$ [27]. Nevertheless, in this study the alumina formed on the $\mathrm{NiAl}$ coating is protective enough to prevent $\mathrm{Cl}$ from penetrating the coating.

The NiCrAlY coating displayed a significant improvement in corrosion behaviour compared to $\mathrm{NiCr}$ but slightly less resistant to the corrosive effect of $\mathrm{KCl}$ than the $\mathrm{NiAl}$ coating. This is probably due to the presence of $\mathrm{Cr}$ in the coating which reacts with $\mathrm{KCl}$ to form $\mathrm{K}_{2} \mathrm{CrO}_{4}$, which is observed on the surface of the coating, see Fig. 10. As seen in the higher-magnification image in the top right corner of Fig. 10, dark contrast lines could be observed to a depth of about $20 \mu \mathrm{m}$ underneath the $\mathrm{K}_{2} \mathrm{CrO}_{4}$ particles. According to EDX analysis, these lines correspond to enrichments of $\mathrm{Cr}, \mathrm{Al}$ and oxygen which indicates the formation of $\mathrm{Cr}$ and $\mathrm{Al}$ oxides. In areas without $\mathrm{K}_{2} \mathrm{CrO}_{4}$ present, the presence of these dark contrast lines was scarce. 
Thus, the formation of $\mathrm{K}_{2} \mathrm{CrO}_{4}$ seems to disrupt the protective oxide on the surface from preventing corrosive species from diffusion through the coating. However, as shown in EDX map for $\mathrm{Cl}$ in the bottom left corner, no diffusion of $\mathrm{Cl}$ through the coating could be observed even underneath the $\mathrm{K}_{2} \mathrm{CrO}_{4}$, which indicates that the thin protective oxide was not fully disrupted. Thus, the NiCrAlY coating succeeds in protecting the substrate from corrosion attack. However, it is unclear how the performance of the coating would be affected by further depletion of $\mathrm{Cr}$ after longer exposures with larger amounts of $\mathrm{KCl}$ or continuous deposition of $\mathrm{KCl}$.

\section{Comparison with Other Spraying Techniques}

Previous studies of different thermal spray coatings used for corrosion resistance have shown that high-alloyed coatings, in the majority of cases, manage to increase the lifetime of the low-alloyed steel substrate in harsh environments. However, since maintenance stops are costly for most applications, the material lifetime is crucial and has to be further improved. The weakness of many coatings is the porosity which has to be as low as possible to achieve a good corrosion resistance. The thermal spraying techniques flame spraying, plasma spraying and HVOF were used, and the microstructure of the as-sprayed coatings were analysed in [28]. For all three coating techniques, a high degree of oxide formation could be observed which is largely negative for the corrosion performance of the coatings. However, it was also shown that optimizing the spraying parameters of the HVOF technique resulted in a much denser coating with less oxide formation. T. Hussain et al. [29] analysed the microstructures of HVOF-sprayed coatings of different composition in which the degree of porosity differed significantly, showing that the composition of the sprayed powder has a large influence on the outcome of the coating microstructure. Sadeghimeresht et al. [30] have recently compared the microstructure of assprayed HVOF and HVAF coatings with the same composition. It was found that the HVAF-sprayed coatings exhibited a lower degree of porosity compared to the HVOF-sprayed coatings.

The HVAF-sprayed coatings in this study appear to exhibit a higher degree of porosity than some of the HVOF- and plasma-sprayed coatings used in previous studies [28, 29, 31]. However, in this study the cross sections of the coatings are not
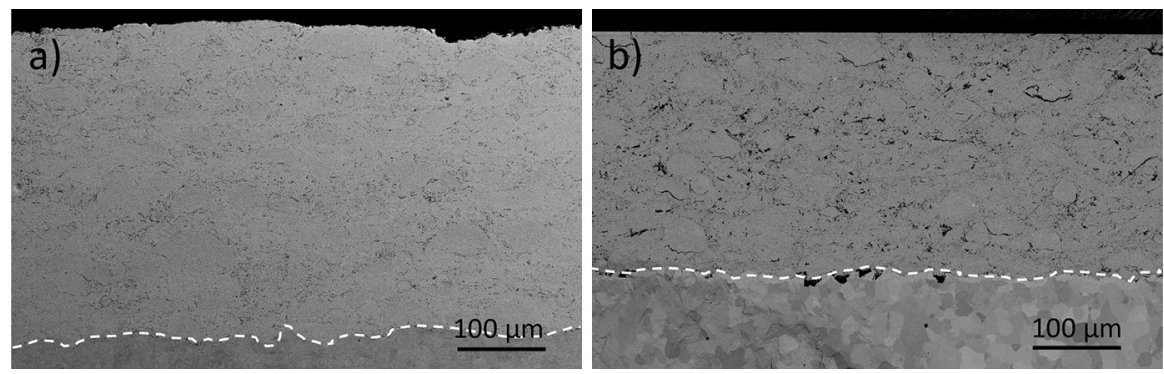

Fig. 11 SEM-BSE cross-sectional images of the NiCrAlY coating after a mechanical polishing and after $\mathbf{b}$ broad ion beam milling. The dashed line indicates the coating/substrate interface 
mechanically polished to achieve a smooth surface. Instead, the cross sections are prepared using broad ion beam milling (BIB) which results in a very smooth surface and facilitates more accurate analysis by making features in the coatings more distinguishable. The difference between mechanically polished surface [32] and a surface prepared by broad ion beam milling can be seen in Fig. 11. As can be seen, the latter appears to be more porous which is due to the surface being smoother, resulting in pores being more visible. Due to this, there is a difficulty in comparing the microstructure of coatings prepared in these two different ways. However, this shows that further optimization of spraying parameters to reduce porosity is needed.

\section{Conclusions}

- None of the three different coatings displayed any spallation during the $168 \mathrm{~h}$ exposure.

- Interdiffusion of $\mathrm{Ni}$ from coating to substrate occurred for all coatings, which led to austenitization in the interdiffusion zone.

- Higher Ni content in the coating led to a higher Ni content in the interdiffusion zone.

- All coatings exposed in $\mathrm{O}_{2}+\mathrm{H}_{2} \mathrm{O}$ at $600{ }^{\circ} \mathrm{C}$ for $168 \mathrm{~h}$ in the absence of $\mathrm{KCl}$ formed thin oxides on the coating surface.

- Oxide formation was observed in the pores/cracks of the NiCr coating.

- After exposure in $\mathrm{O}_{2}+\mathrm{H}_{2} \mathrm{O}$ at $600{ }^{\circ} \mathrm{C}$ for $168 \mathrm{~h}$ in the presence of $\mathrm{KCl}$, the severity of the corrosion attack differed significantly between the different coatings.

- The NiCr coating exhibited severe corrosion attack, leading to the formation of a thick oxide on the coating surface as well as $\mathrm{Cl}$ penetration, reaching to the substrate.

- The NiCrAlY coating displayed formation of $\mathrm{K}_{2} \mathrm{CrO}_{4}$ on the surface and minor oxide formation underneath these but was able to prevent $\mathrm{Cl}$-diffusion.

- The NiAl coating displayed a good corrosion resistance and prevented all corrosive species $(\mathrm{O}$ and $\mathrm{Cl})$ from diffusing through the coating.

Acknowledgements This work was a collaboration between the Swedish High Temperature Corrosion Center (HTC) and the Department of Engineering at University West. Financial support of the Knowledge Foundation for the SCoPe project (RUN 2016-0201) and Västra Götalandsregionen (VGR) for the PROSAM project (RUN 2016-01489) is highly acknowledged. The authors would like to thank Jonas Olsson, Stefan Björklund and Kenneth Andersson for their valuable help and advice in processing and characterization of the HVAF coatings in this study.

Open Access This article is distributed under the terms of the Creative Commons Attribution 4.0 International License (http://creativecommons.org/licenses/by/4.0/), which permits unrestricted use, distribution, and reproduction in any medium, provided you give appropriate credit to the original author(s) and the source, provide a link to the Creative Commons license, and indicate if changes were made. 


\section{References}

1. Climate Hot Map_Global Warming Effects Around The World (2011). http://www.climatehotmap. org/. Accessed August 29th, 2017.

2. H. P. Nielsen, F. J. Frandsen, K. Dam-Johansen and L. L. Baxter, The implications of chlorineassociated corrosion on the operation of biomass-fired boilers. Progress in Energy and Combustion Science 26, 283-298 (2000).

3. K. O. Davidsson, L.-E. Åmand, B. Leckner, et al., Potassium, chlorine, and sulfur in ash, particles, deposits, and corrosion during wood combustion in a circulating fluidized-bed boiler. Energy and Fuels 21, 71-81 (2007).

4. H. P. Michelsen, F. Frandsen, K. Dam-Johansen and O. H. Larsen, Deposition and high temperature corrosion in a $10 \mathrm{MW}$ straw fired boiler. Fuel Processing Technology 54, 95-108 (1998).

5. K. G. Field, M. A. Snead, Y. Yamamoto and K. A. Terrani, Handbook on the Material Properties of FeCrAl Alloys for Nuclear Power Production Applications, (Oak Ridge National Laboratory, Oak Ridge, 2017).

6. S. Chen and L. Rong, Effect of silicon on the microstructure and mechanical properties of reduced activation ferritic/martensitic steel. Journal of Nuclear Materials. 459, 13-19 (2015).

7. L. Song, E. Guo, L. Wang and D. Liu, Effects of silicon on mechanical properties and fracture toughness of heavy-section ductile cast iron. Metals 5, 150-161 (2015).

8. A. Hjörnhede and A. Nylund, Adhesion testing of thermally sprayed and laser deposited coatings. Surface and Coatings Technology 184, 208-218 (2004).

9. A. Hjörnhede, P. Sotkovszki and A. Nylund, Erosion-corrosion of laser and thermally deposited coatings exposed in fluidised bed combustion plants. Materials and Corrosion 57, 307-322 (2006).

10. E. Sadeghimeresht and N. Markocsan, Electrochemical behavior of bilayer thermal-spray coatings in low-temperature corrosion protection. Coatings 7, 162 (2017).

11. E. Sadeghimeresht, J. Eklund, J. Phother Simon, J. Liske, N. Markocsan and S. Joshi, Effect of water vapor on the oxidation behavior of HVAF-sprayed $\mathrm{NiCr}$ and $\mathrm{NiCrAlY}$ coatings. Materials and Corrosion 69, 1431-1440 (2018).

12. Z. Zeng, N. Sakoda, T. Tajiri and S. Kuroda, Structure and corrosion behavior of 316L stainless steel coatings formed by HVAF spraying with and without sealing. Surface and Coatings Technology 203, 284-290 (2008).

13. E. Sadeghimeresht, N. Markocsan, P. Nylén and S. Björklund, Corrosion performance of bi-layer $\mathrm{Ni} / \mathrm{Cr} 2 \mathrm{C} 3-\mathrm{NiCr}$ HVAF thermal spray coating. Applied Surface Science 369, 470-481 (2016).

14. B. A. Pint, Y. Zhang, J. A. Haynes, I. G. Wright, High Temperature Oxidation Performance of Aluminide Coatings (City; Oak Ridge National Lab., Oak Ridge, TN; Tennessee Technological University Cookeville, TN (US), 2003).

15. B. A. Pint, Y. Zhang, L. R. Walker and I. G. Wright, Long-term performance of aluminide coatings on Fe-base alloys. Surface and Coatings Technology 202, 637-642 (2007).

16. D. Texier, D. Monceau, Z. Hervier and E. Andrieu, Effect of interdiffusion on mechanical and thermal expansion properties at high temperature of a MCrAlY coated Ni-based superalloy. Surface and Coatings Technology 307, 81-90 (2016).

17. L. Niewolak, E. Wessel, T. Hüttel, C. Asensio-Jimenez, L. Singheiser and W. Quadakkers, Behavior of interconnect steels in carbon containing simulated anode gas of solid oxide fuel cells. Journal of the Electrochemical Society 159, F725-F732 (2012).

18. G. E. Totten, Handbook of Residual Stress and Deformation of Steel, (ASM international, „Almere;, 2002).

19. F. Cverna, Thermal Properties of Metals, (ASM International, Materials Park, 2002).

20. Y. Zhang, A. P. Liu and B. A. Pint, Interdiffusional degradation of oxidation-resistant aluminide coatings on Fe-base alloys. Materials and Corrosion 58, 751-761 (2007).

21. E. Sadeghimeresht, N. Markocsan, M. Huhtakangas and S. Joshi, Isothermal oxidation of HVAFsprayed Ni-based chromia, alumina and mixed-oxide scale forming coatings in ambient air. Surface and Coatings Technology 316, 10-21 (2017).

22. H. Asteman, K. Segerdahl, J. E. Svensson et al, Oxidation of stainless steel in H2O/O-2 environments-role of chromium evaporation, in High Temperature Corrosion and Protection of Materials 6, Prt 1 and 2, Proceedings, eds. P. Steinmetz, I. G. Wright, G. Meier, A. Galerie, B. Pieraggi, R. Podor (Trans Tech Publications Ltd, Zurich, 2004), pp. 775-782. 
23. J. Pettersson, H. Asteman, J. E. Svensson and L. G. Johansson, KCl induced corrosion of a 304-type austenitic stainless steel at $600^{\circ} \mathrm{C}$. The Role of Potassium. Oxidation of Metals 64, 23-41 (2005).

24. R. Jafari, E. Sadeghimeresht, T. S. Farahani, M. Huhtakangas, N. Markocsan and S. Joshi, KClinduced high-temperature corrosion behavior of HVAF-sprayed ni-based coatings in ambient air. Journal of Thermal Spray Technology 27, 500-511 (2018).

25. H. Kassman, M. Broström, M. Berg and L.-E. Åmand, Measures to reduce chlorine in deposits: application in a large-scale circulating fluidised bed boiler firing biomass. Fuel 90, 1325-1334 (2011).

26. P. Steinmetz and C. Rapin, Corrosion of metallic materials in waste incinerators. Materials Science Forum 251-254, 505-518 (1997).

27. N. Israelsson, High temperature oxidation and chlorination of FeCrAl alloys. PhD Thesis, Gothenburg; Chalmers University of Technology, 2014.

28. L. N. Moskowitz, Application of HVOF thermal spraying to solve corrosion problems in the petroleum industry - an industrial note. Journal of Thermal Spray Technology 2, 21-29 (1993).

29. T. Hussain, T. Dudziak, N. J. Simms and J. R. Nicholls, Fireside corrosion behavior of HVOF and plasma-sprayed coatings in advanced coal/biomass co-fired power plants. Journal of Thermal Spray Technology 22, 797-807 (2013).

30. E. Sadeghimeresht, N. Markocsan and P. Nylén, Microstructural characteristics and corrosion behavior of HVAF- and HVOF-sprayed Fe-based coatings. Surface and Coatings Technology 318, 365-373 (2017).

31. T. Varis, D. Bankiewicz, P. Yrjas, et al., High temperature corrosion of thermally sprayed $\mathrm{NiCr}$ and $\mathrm{FeCr}$ coatings covered with a $\mathrm{KCl}-\mathrm{K} 2 \mathrm{SO} 4$ salt mixture. Surface and Coatings Technology $\mathbf{2 6 5}$, 235-243 (2015).

32. E. Sadeghimeresht, L. Reddy, T. Hussain, M. Huhtakangas, N. Markocsan and S. Joshi, Influence of $\mathrm{KCl}$ and $\mathrm{HCl}$ on high temperature corrosion of HVAF-sprayed NiCrAlY and NiCrMo coatings. Materials and Design 148, 17-29 (2018).

Publisher's Note Springer Nature remains neutral with regard to jurisdictional claims in published maps and institutional affiliations. 